\title{
IDENTIFICATION OF SPATIAL AND TECHNICAL PARAMETERS OF AGRICULTURAL LAND IN THE RIBBON LAND LAYOUT
}

\author{
Justyna Wójcik-Leń, Izabela Skrzypczak, Grzegorz Oleniacz, Karol Ożóg, \\ Przemysław Leń
}

\begin{abstract}
Summary
Each developed area in which there are various objects is characterized by specific structures that together form a broadly understood spatial structure. It covers spatial and natural objects as well as those resulting from human activities. Unfortunately, the spatial structure of the Polish countryside seems to be increasingly unfavourable. Rural areas in different regions of Poland are characterized by different spatial parameters. Therefore, it is necessary to carry out detailed research and analysis enabling the selection of appropriate factors describing the area under study in terms of determining the urgency of undertaking comprehensive land consolidation and exchange works, as rural areas in Poland need deep structural changes related to agricultural production, farm size, shaping land layout, demographic, spatial and institutional structure. The selection of factors describing the examined villages was made on the basis of a comprehensive analysis of the natural, social and economic conditions of the villages on the basis of data obtained from the Land and Property Register of the County Office in Opoczno and data from the Żarnów commune. The research results will allow the selection of the most important factors characterizing the spatial structure of the research area. The purpose of the paper is to identify the spatial and technical parameters of agricultural lands in the villages of Central Poland on the example of the Żarnów commune, which will be the starting point for determining the needs of land consolidation works in 41 villages of the Żarnów commune, located in the Opoczno poviat, the Łódź voivodship.
\end{abstract}

\section{Keywords}

land consolidation $\bullet$ arable land $\bullet$ defective spatial structure of rural areas

\section{Introduction}

The land consolidation and exchange process plays a very important role in arranging rural spaces. Excessive fragmentation and dispersion of farms as well as their irregular shapes, size and area have a negative impact on the rational use of land resources, agricultural development and its profitability. Natural and climatic conditions of the 
studied area, poor infrastructure and the lack of access roads are further factors exerting a bad influence on the effective operation of machines, productivity and costs of work related to farming.

The current spatial structure of the village is a result of long-lasting socio-economic and demographic processes. Lots of lands are fragmented due to, among others, continuous ownership divisions, inheritance of farms, overcrowding and difficult migration processes. To improve the operation of the Polish agricultural sector and increase competitiveness, work is needed to improve the area structure of farms. According to the Rural Development Program for 2014-2020, land consolidation is presented as a work involving demarcation of new cadastral plots with a different shape compared to the original ones, in order to reduce the number of small, dispersed plots that make up the farm, and to enlarge them to medium size. As part of the consolidation project, works are also carried out in the field of post-consolidation land development, which include, in particular, the creation of a functional network of access roads to agricultural and forest lands and the implementation of tasks affecting the regulation of water in the area of consolidation.

The problem of large defects in the spatial structure of agricultural lands concerns many countries of Central Europe [Sonnenberg 2002, van Dijk 2003, Vitikainen 2004]. This phenomenon and its negative consequences are also present in other parts of Europe and the world [Latruffe and Piet 2013]. In the world literature, the authors note that the most important flaws in the spatial structure include large fragmentation of land. This problem is the subject of research of many authors: Karouzis [1977], King and Burton [1982], Bentley [1987], Blaiki and Sadeque [2000], Hung et al. [2001], Gulinck and Wagendorp [2002], Van Dijk [2004], Niroula and Thapa [2005], Tan et al. [2006], Hartvigsen [2006], Hung et al. [2007], Rahman and Rahman [2008], Hartvigsen [2015], Hudecová et al. [2016], Janus et al. [2016], Wenbo Li et al. [2017], Kwinta and Gniadek [2017]. The above-mentioned factors regarding the use, ownership and geometry of plots, the lack of access roads and other features affecting the faulty spatial structure of lands will be analysed in detail in this work in adaptation to various research areas.

In the first place, however, a detailed analysis of the spatial structure of the studied area should be made, which will allow the selection of factors containing current, reliable information about these objects, with the help of which it is possible to characterize the studied area in order to better use the rural space. It should be noted here that rural areas can be characterized by many different factors that provide information on the degree of defectiveness of the spatial structure of lands.

Based on the data of the descriptive and graphic parts obtained from the Land and Property Register, a series of data was obtained on the spatial structure of rural areas in 41 villages of the Żarnów commune in the Opoczno poviat, the Łódź voivodship. The first group includes factors describing general information about the studied precincts in the commune, such as: $x_{1}$ - total area, $x_{2}$ - total number of plots, $x_{3}$ - number of inhabitants, $x_{4}$ - number of inhabitants per $\mathrm{km}^{2}, x_{5}-\%$ of the area of individual farms, $x_{6}-\%$ of the number of plots of individual farm lands, $x_{7}$ - average plot area (group 7). The second group consists of factors concerning individual farm lands such as: 
$x_{8}$ - number of registration units 7.1, $x_{9}-\%$ of registration units 7.1, $x_{10}$ - number of plots of a registration unit 7.1, $x_{11}$ - area of plots of a registration unit 7.1, $x_{12}-\%$ of the number of plots 7.1 in relation to group $7, x_{13}-\%$ of the plot area in relation to group 7 , $x_{14}$ - average number of plots in a registration unit, $x_{15}$ - average area of a registration unit, $x_{16}-$ fragmentation index. The next group concerns the productivity index, which consists of the following factors: $x_{17}$ - of arable lands, $x_{18}$ - of grasslands. The fourth group belongs to factors concerning the ownership structure, in which we distinguish: $x_{19}-\%$ of land owned by the Agricultural Property Agency of State Treasury, group $1.1, x_{20}$ - land owned by the communes. In the fifth group, regarding plots without road access, the following factors are included: $x_{21}-\%$ of the number of plots without road access, $x_{22}-\%$ of the plot area without road access. Group 6 consists of factors concerning the structure of land use, which includes the following factors: $x_{23}-\%$ share of orchards, $x_{24}-\%$ share of forests. The last group of factors is: $x_{25}-\%$ of the number of plots below the elongation index of $1.00, x_{26}-\%$ of the area of plots below the elongation index of 1.00, $x_{27}-\%$ of the number of plots with the elongation index value of $1.01-2.00, x_{28}-\%$ of the area of plots with the elongation index of $1.01-2.00, x_{29}-\%$ of the number of plots with the elongation index value of $2.01-3.00, x_{30}-\%$ of the area of plots with the elongation index value of 2.01-3.00, $x_{31}$ - synthetic plot elongation index for the precinct, $x_{32}$ - average value of the elongation index.

The purpose of the paper is to identify the spatial and technical parameters of agricultural lands in the villages of Central Poland on the example of the Żarnów commune, which will be the starting point for determining the needs of land consolidation works in 41 villages of the Żarnów commune, located in the Opoczno poviat.

\section{Analysis of the spatial structure of the Żarnów commune}

\subsection{Structure of land ownership and use}

The land ownership structure defines the distribution of individual farms and record parcels in relation to the total land area, taking into account the distribution in a given area and their size. Legal and ownership relations of lands in the studied area are determined primarily by the land relief and ownership forms. According to Table 1, 10,962.11 ha of the area of the Żarnów commune belong to natural persons, which is $77.71 \%$. In the examined area, out of forty-one villages only in four of them, the land ownership share of natural persons did not exceed 50.0\%. They are respectively: Siedlów, where the percentage of land belonging to individual farms is $25.58 \%$; Adamów, in which natural persons hold $32.32 \%$ of the total land; Myślibórz, where $32.98 \%$ of the land belongs to natural persons; and Kamieniec, where $35.87 \%$ of the land belongs to individuals. The largest area of farms belonging to Group 7 is in Skumros, where the percentage is as much as $98.39 \%$ of the total examined area.

The second largest group are lands belonging to the Treasury, if they do not coincide with perpetual lessees, which occupy 2534.26 ha, representing $17.96 \%$ of the total area of the commune. In this range, $14.07 \%$ of the total area of the commune is occupied 
by the State Forests, while the lands belonging to the National Agricultural Support Centre (KOWR) occupy a total of 105.51 ha $(0.75 \%)$. Most of the lands in the registration subgroup 1.2, in terms of percentage relation to the total area of individual villages, are located in: Adamów (65.64\%). Kamieniec (53.71\%). Myślibórz (53.42\%). Siedlów (48.04\%). Sielec (38.76\%) and Bronów (31.91\%).

The third group in terms of surface area consists lands owned by the communes and intercommunal associations, if they are not convergent with perpetual lessees. This group includes 414.14 ha of area, representing 2.94\% of the total area of the Żarnów commune. This group has the largest share in the town of Żarnów (10.03\% of the total area of the village). Other forms of ownership constitute a small percentage.

Table 1. The ownership structure of the Żarnów commune

\begin{tabular}{|c|c|c|c|c|}
\hline Ordinal & Registration Group Name & $\begin{array}{c}\text { Group } \\
\text { number }\end{array}$ & $\begin{array}{l}\text { Surface area } \\
\quad[\text { ha }]\end{array}$ & $\%$ \\
\hline 1 & $\begin{array}{l}\text { The Treasury, if it does not coincide with a perpetual } \\
\text { lessee }\end{array}$ & 1 & 105.51 & 0.75 \\
\hline 2 & $\begin{array}{l}\text { The Treasury, if it does not coincide with a perpetual } \\
\text { lessee }\end{array}$ & 1 & 1984.75 & 14.07 \\
\hline 3 & $\begin{array}{l}\text { The Treasury, if it does not coincide with a perpetual } \\
\text { lessee }\end{array}$ & 1 & 444 & 3.15 \\
\hline 4 & $\begin{array}{l}\text { Communes and inter-commune associations if they do } \\
\text { not coincide with perpetual lessees }\end{array}$ & 4 & 414.14 & 2.94 \\
\hline 5 & Treasury plots of land transferred for perpetual usufruct & 2 & 13.51 & 0.1 \\
\hline 6 & Land owned by local government bodies & 6 & 3.1 & 0.02 \\
\hline 7 & Natural persons & 7 & 10962.11 & 77.71 \\
\hline 8 & Lands owned by cooperatives & 8 & 54.35 & 0.39 \\
\hline 9 & Lands owned by churches and religious associations & 9 & 22.54 & 0.16 \\
\hline 10 & Land owned by land communities & 10 & 2.34 & 0.02 \\
\hline 11 & $\begin{array}{l}\text { Lands owned by poviats, if it does not coincide with } \\
\text { a perpetual lessee }\end{array}$ & 11 & 44.45 & 0.32 \\
\hline 12 & $\begin{array}{l}\text { Lands owned by commercial law companies and other } \\
\text { registration entities not mentioned in points } 1-14\end{array}$ & 15 & 56.11 & 0.4 \\
\hline \multicolumn{3}{|l|}{ Total: } & 14106.91 & 100.0 \\
\hline
\end{tabular}

Source: Authors' own study

In the land use structure (Fig. 1), the largest share is arable land, the area of which is 9646.04 ha, which is $69.02 \%$ of the total area of the commune in question. 


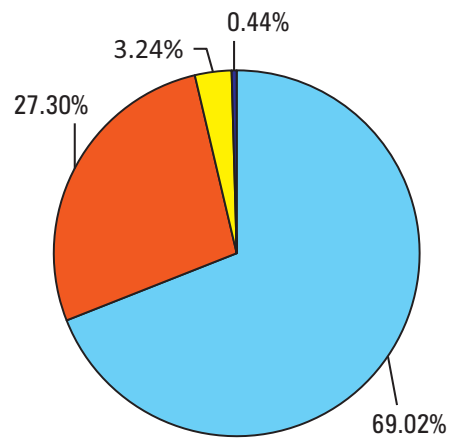

Arable lands

Forest lands

Built-up and urbanized lands

Lands under ponds

Source: Authors' own study

Fig. 1. Percentage summary of structure of use in the Żarnów commune

Arable lands cover 6518.88 ha of area, which is $46.21 \%$, the largest in this group. Next are permanent pastures, which cover an area of 1372.96 ha $(9.73 \%)$, permanent meadows with 1179.38 ha $(8.36 \%)$, built-up arable lands with 324.79 ha $(2.30 \%)$. The smallest share are orchards, ditches and lands under ponds, which cover an area of 250.05 ha, constituting $1.78 \%$ of the total area. Another significant group identified during the analysis are forest, tree-covered and shrub-covered lands, which cover an area of 3851.52 ha, which is $27.30 \%$ of the examined commune. Built-up and urbanized lands constitute 456.71 ha, which is $3.24 \%$ of the commune area, of which the largest part is roads $(2.62 \%)$, while the smallest is in industrial areas, which occupy only $0.05 \%$ of the commune. Other usable lands account for a small percentage.

\subsection{Analysis of land fragmentation}

The analysis of the fragmentation structure of the Żarnów commune (Fig. 2) showed a very large fragmentation of cadastral plots. Plots not exceeding 0.10 ha constitute as much as $20.9 \%$, and their number is 4726 . Most plots belonging to natural persons are in the range of $0.11-0.30$ ha and there are 7583 of them, which is $33.5 \%$ of the total number of plots. The plots constituting $21.7 \%$ in this area are plots in the area range of $0.31-0.60$ ha. Their number is 4918 . The area range of $0.61-1.00$ ha includes 2748 farms owned by natural persons, which constitutes $12.1 \%$ of the total number of plots of persons belonging to group 7. There are 2663 individual farms in the Żarnów commune with an area larger than 1.01 ha. This number represents $11.8 \%$ of all plots owned by natural persons in the examined commune.

In order to parameterize fragmentation, a synthetic fragmentation index was calculated for all locations of the Żarnów commune. For each of the surface groups, a weight was assigned from 1 - the sector of plots of land not exceeding the area of 0.10 ha; up to 5 - constituting plots of land belonging to natural persons with the area of over 1.01 ha. The fragmentation index is described according to the following formula [Len and Noga 2010]: 


$$
W_{r}=\frac{\sum_{1}^{n}\left(x_{n} \cdot l_{n}\right)}{p}
$$

where:

$x_{n}$ - area of cadastral plots in the examined area,

$l_{n}$ - weight for each sector from 1-5,

$P$ - total area of individual lands in the village.

The analysis of the fragmentation index of the Żarnów commune showed that the smallest indicator of land fragmentation is in Nowa Góra, where the index is 2.63. The highest fragmentation rate was recorded in Chełsty and it amounts to 4.41. The smallest average area of plots in the individual sector is in Nowa Góra (0.20 ha), while the largest in Malenie - 1.38 ha.

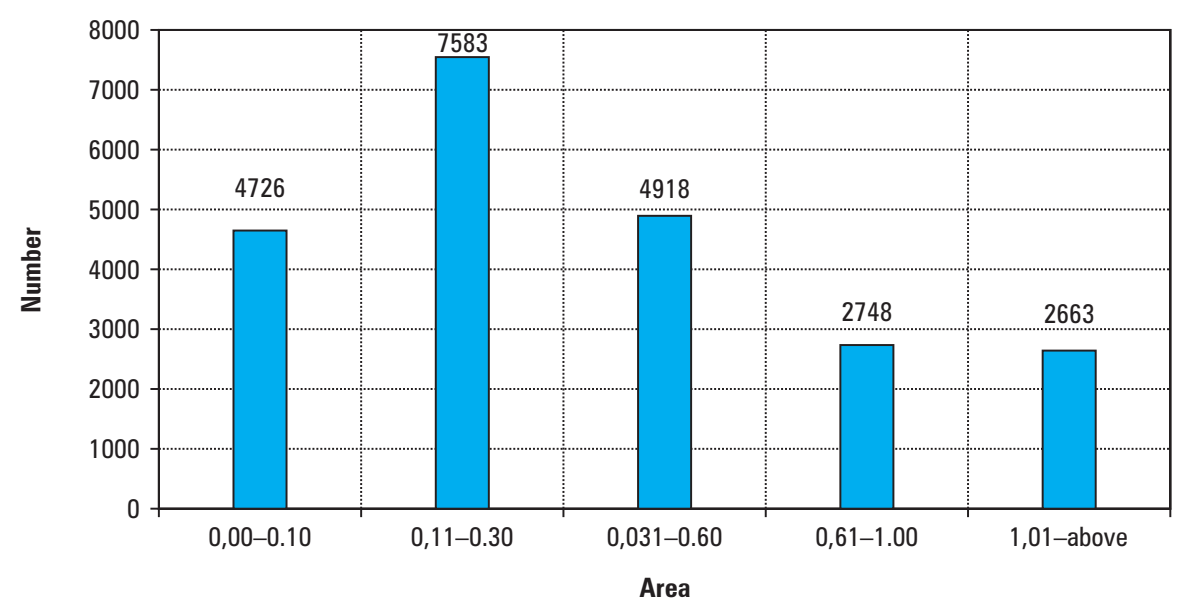

Source: Authors' own study

Fig. 2. Land fragmentation in the Żarnów commune

\subsection{Analysis of the road network of agricultural transport}

Currently, the agricultural transport network consists mainly of unpaved dirt roads, very often impassable. This network may also be excessively thin, which results in a lack of proper access to fields or too dense, in the case of large fragmentation. Such a case facilitates access to fields, but as a consequence it is associated with arable land surface losses, and also worsens the conditions for separating fields of convenient shape and area [Radziszewska and Jaroszewicz 2012]. According to Noga, plots that do not have access to the road generate a double loss because they entail additional costs associated with cultivation and informal passages through plots belonging to other owners, which generates losses and even leads to conflicts [Noga 2001]. The access from plots to roads 


\begin{tabular}{|c|c|c|c|c|c|c|c|c|c|c|c|c|c|c|}
\hline \multirow{12}{*}{ 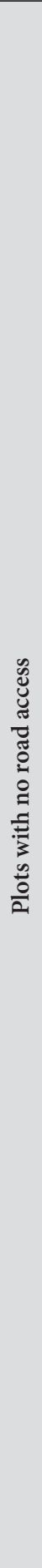 } & 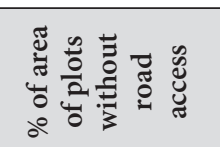 & $\stackrel{\underline{v}}{\mathrm{v}}$ & $\stackrel{H}{+}$ & $\stackrel{\infty}{ \pm}$ & $\stackrel{0}{=}$ & $\stackrel{H}{0}$ & $\stackrel{\infty}{+}$ & $\begin{array}{l}\mathbf{0} \\
\stackrel{ \pm}{-}\end{array}$ & H' & $m^{m}$ & $\begin{array}{l}0 \\
0 \\
0\end{array}$ & $\begin{array}{l}\infty \\
\sim^{\infty}\end{array}$ & $\overrightarrow{6}$ & $\vec{n}$ \\
\hline & 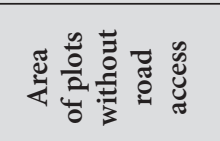 & $\stackrel{\infty}{\sim}$ & $\stackrel{\sim}{\sim}$ & 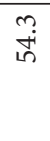 & $\stackrel{\infty}{i}$ & $\lesssim$ & $\stackrel{n}{\mathrm{I}}$ & $\stackrel{10}{2}$ & $\stackrel{-}{\circ}$ & $\stackrel{n}{=}$ & $\overrightarrow{\text { in }}$ & 穴 & 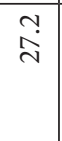 & $\stackrel{+}{\stackrel{+}{*}}$ \\
\hline & 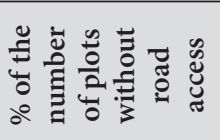 & $\begin{array}{l}\text { Mo } \\
\infty \\
0 \\
0\end{array}$ & $\begin{array}{l}\stackrel{10}{+} \\
\dot{n}\end{array}$ & $\begin{array}{l}\infty \\
+\infty \\
\infty \\
-\infty\end{array}$ & $\begin{array}{l}\infty \\
\stackrel{\infty}{0} \\
\text { I }\end{array}$ & $\begin{array}{l}\stackrel{2}{n} \\
\stackrel{2}{2} \\
2\end{array}$ & 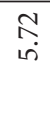 & $\begin{array}{l}\text { त̂ } \\
\text { ה }\end{array}$ & $\stackrel{\mathscr{\Omega}}{\dot{\gamma}}$ & $\underset{\sim}{0}$ & $\stackrel{2}{\circ}$ & $\begin{array}{l}+ \\
\stackrel{2}{\sigma} \\
\sigma\end{array}$ & $\hat{\Xi}$ & $\begin{array}{l}\text { ņ } \\
\text { mं }\end{array}$ \\
\hline & 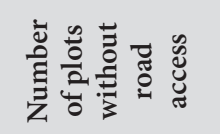 & ت艹 & in & ন゙ & $\stackrel{\circ}{\sim}$ & $\stackrel{m}{m}$ & $\stackrel{\leftrightarrow 2}{\sim}$ & $尺$ & in & $m$ & $\stackrel{10}{2}$ & $\vec{\sim}$ & İ & $\stackrel{\infty}{\infty}$ \\
\hline & 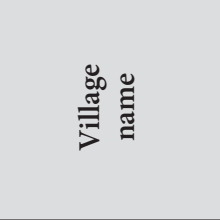 & 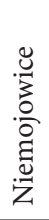 & 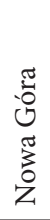 & 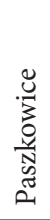 & 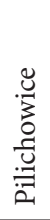 & 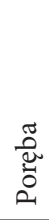 & 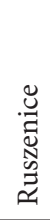 & 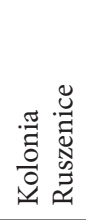 & 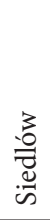 & $\frac{\mathscr{U}}{\tilde{U}}$ & 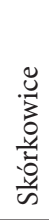 & 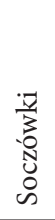 & 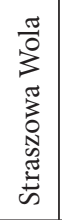 & 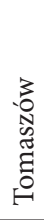 \\
\hline & : & ป & 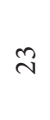 & $\stackrel{H}{\sim}$ & $\stackrel{\stackrel{2}{\sim}}{ }$ & 루 & $\hat{\curvearrowright}$ & $\stackrel{\infty}{\sim}$ & సે & ిల & $\vec{n}$ & लె & $\tilde{m}$ & ले \\
\hline & 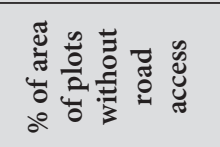 & 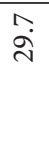 & $\stackrel{\circ}{\circ}$ & $\stackrel{\sigma}{\partial}$ & $\begin{array}{l}\infty \\
\dot{1}\end{array}$ & $\begin{array}{l}\text { ?n } \\
\stackrel{9}{9}\end{array}$ & $\stackrel{m}{9}$ & $\stackrel{9}{-}$ & $\stackrel{H}{0}$ & $\begin{array}{l}\dot{r} \\
\dot{m}\end{array}$ & זु. & $\stackrel{\text { in }}{\underset{+}{+}}$ & $\stackrel{\sim}{\sim}$ & $\stackrel{0}{=}$ \\
\hline & 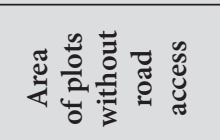 & ח̊̀ & $\begin{array}{l}0 \\
\stackrel{0}{0} \\
-1\end{array}$ & $\stackrel{m}{m}$ & $\underset{0}{\infty}$ & $\vec{i}$ & $\begin{array}{l}\circ \\
\text { îj }\end{array}$ & $\stackrel{+}{+}$ & $\stackrel{\circ}{\circ}$ & $\stackrel{9}{\exists}$ & $\stackrel{\sim}{2}$ & $\begin{array}{l}\not{D} \\
\infty \\
\infty \\
\infty\end{array}$ & $\vec{m}$ & $\stackrel{\circ}{\stackrel{0}{\circ}}$ \\
\hline & 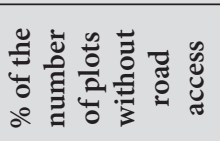 & શิ & $\begin{array}{l}\overrightarrow{+} \\
\dot{+}\end{array}$ & 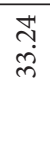 & $\begin{array}{l}\text { m. } \\
m \\
m\end{array}$ & ָे & $\begin{array}{l}\infty \\
\stackrel{0}{2} \\
\stackrel{\sim}{1}\end{array}$ & ర్ర & $\underset{\sim}{\stackrel{8}{\circ}}$ & $\stackrel{m}{m}$ & $\begin{array}{l}2 \\
\infty \\
\infty \\
\infty\end{array}$ & $\stackrel{\curvearrowright}{\wedge}$ & \begin{tabular}{l}
\multirow{2}{*}{} \\
$\stackrel{+}{+}$ \\
$\stackrel{\infty}{m}$
\end{tabular} & $\begin{array}{l}\infty \\
\stackrel{\infty}{\infty} \\
\infty \\
+\end{array}$ \\
\hline & 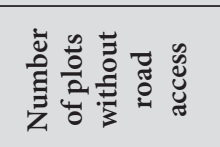 & $\stackrel{\text { త్ }}{ }$ & $\ddot{m}$ & $\stackrel{10}{=}$ & $\exists$ & $\vec{n}$ & $\stackrel{\infty}{+}$ & $\stackrel{\infty}{\sim}$ & in & ले & $\frac{n}{m}$ & in & $\stackrel{\uplus}{\exists}$ & 우 \\
\hline & 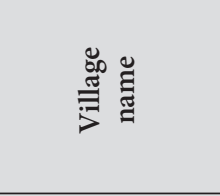 & 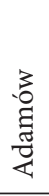 & 峦 & 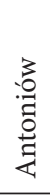 & $\begin{array}{l}3 \\
0 \\
0 \\
0 \\
0\end{array}$ & 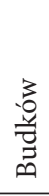 & 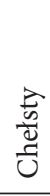 & $\frac{\pi}{\pi}$ & 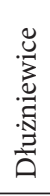 & 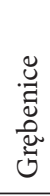 & 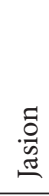 & $\frac{3}{\square}$ & $\begin{array}{c}3 \\
0 \\
0 \\
.0 \\
0 \\
0 \\
0 \\
0 \\
0\end{array}$ & 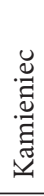 \\
\hline & 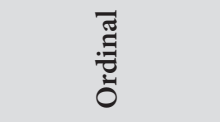 & - & $N$ & $m$ & $r$ & in & 6 & $\wedge$ & $\infty$ & $a$ & $\stackrel{-}{\circ}$ & $\exists$ & $I$ & $\stackrel{m}{-1}$ \\
\hline
\end{tabular}




\begin{tabular}{|c|c|c|c|c|c|c|c|c|c|}
\hline \multirow{12}{*}{ 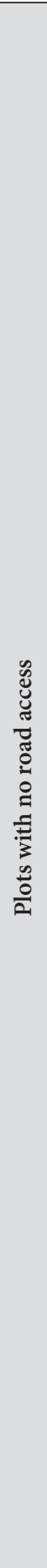 } & 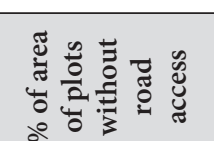 & $\hat{o}$ & $\hat{\hat{\delta}}$ & $\begin{array}{l}\mathrm{Ln}^{2} \\
\mathrm{in}\end{array}$ & $\stackrel{H}{i n}$ & tr. & $\stackrel{H}{-}$ & $\stackrel{H}{\infty}$ & $\stackrel{m}{\stackrel{0}{0}}$ \\
\hline & 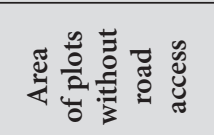 & $\stackrel{\infty}{+\infty}$ & 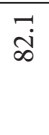 & $\hat{a}$ & ָี & $\ddot{0}$ & $\begin{array}{l}\infty \\
\infty \\
\infty\end{array}$ & $\underset{f}{q}$ & $\stackrel{\infty}{\stackrel{g}{+}}$ \\
\hline & 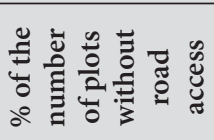 & ت্ت & $\begin{array}{l}2 \\
\text { in } \\
\text { in }\end{array}$ & $\begin{array}{l}\vec{n} \\
\infty \\
\infty\end{array}$ & 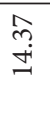 & ભે & $\underset{i}{\stackrel{H}{*}}$ & $\stackrel{\infty}{\stackrel{\infty}{=}}$ & 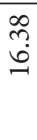 \\
\hline & 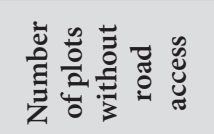 & $\stackrel{\mathscr{n}}{\sim}$ & $\stackrel{\infty}{\sim}$ & $\stackrel{\sim}{\sim}$ & $\stackrel{\widehat{m}}{n}$ & $\sim$ & $\stackrel{\infty}{\sim}$ & $\underset{\sim}{\mathbb{H}}$ & $\begin{array}{l}\text { مै } \\
\stackrel{1}{f}\end{array}$ \\
\hline & 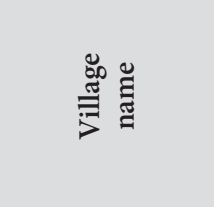 & 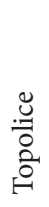 & 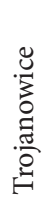 & 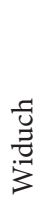 & 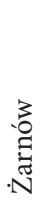 & $\begin{array}{l}0 \\
\stackrel{0}{\Xi} \\
\text { 壳 }\end{array}$ & 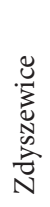 & 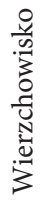 & 㺃 \\
\hline & 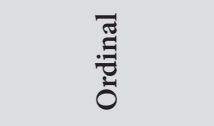 & $\stackrel{m}{m}$ & r & nิ & $\stackrel{\infty}{\infty}$ & ले & 우 & $F$ & \\
\hline & 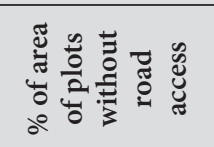 & $\stackrel{10}{\circ}$ & $\stackrel{\infty}{i n}$ & $\stackrel{\infty}{\sim}$ & $\stackrel{\mathscr{L}}{\mathrm{I}}$ & $\stackrel{\circ}{\wedge}$ & 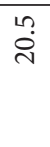 & $\vec{a}$ & $\stackrel{+}{\stackrel{\Delta}{N}}$ \\
\hline & 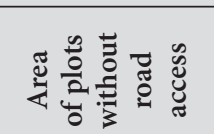 & $\stackrel{\circ}{\circ}$ & $\stackrel{\sim}{+}$ & $\stackrel{0}{\sim}$ & $\hat{i}$ & $\stackrel{m}{m}$ & तே. & 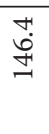 & में \\
\hline & 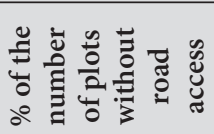 & $\begin{array}{l}\vec{b} \\
\stackrel{0}{-}\end{array}$ & $\stackrel{m}{\omega}$ & $\begin{array}{l}\qquad 0 \\
\stackrel{+}{0} \\
+\end{array}$ & 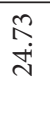 & $\begin{array}{l}\stackrel{\bullet}{\vec{\lambda}} \\
\stackrel{\sim}{N}\end{array}$ & 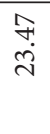 & $\begin{array}{l}\tilde{\infty} \\
\dot{0} \\
\dot{\omega}\end{array}$ & $\begin{array}{l}\stackrel{8}{0} \\
\dot{\gamma}\end{array}$ \\
\hline & 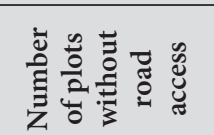 & $\vec{\sim}$ & $\stackrel{\circ}{\sim}$ & $\stackrel{m}{m}$ & $\stackrel{\uplus}{\exists}$ & ڤั & $\underline{n}$ & $\Xi$ & 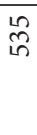 \\
\hline & 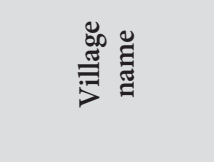 & 穿 & $\frac{\mathscr{0}}{\frac{\tilde{\omega}}{\tilde{\Xi}}}$ & 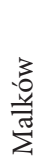 & 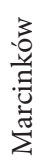 & 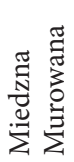 & 竞 & 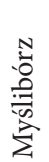 & $\begin{array}{l}\frac{0}{0} \\
\frac{0}{\pi} \\
\text { ż }\end{array}$ \\
\hline & 苂 & $\Xi$ & $\stackrel{10}{n}$ & $\stackrel{0}{\sim}$ & 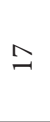 & $\stackrel{\infty}{\sim}$ & 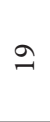 & $\stackrel{\sim}{\sim}$ & $\vec{\sim}$ \\
\hline
\end{tabular}


depends on the distance between the roads and the length of the plots. The road network providing access to each plot is achievable in two ways. There may be one or two rows of plots between adjacent roads. Access to plots from one side is more beneficial for short plots (up to $180 \mathrm{~m}$ ), because it increases the distance between neighbouring roads and leads to a decrease in road density. For longer plots, it is beneficial to secure access to roads from two sides, as the cultivation costs are much lower than in the case of onesided access [Harasimowicz et al. 2012].

According to the analysis (Table 2) in the commune of Żarnów, the number of plots without road access is 4576 , which is $16.38 \%$ of the total number of plots in the commune. Plots without road access occupy $10.28 \%$ of the entire area of the commune. In the analysed commune, the Jasion precinct is the worst, in which the number of plots without road access is 315 , constituting $58.99 \%$ of the number of plots within. The best situation is in Skumros, where only 2 plots do not have an access road.

\subsection{Geometry analysis of cadastral plots}

The performed research showed that the studied area has unfavourable plot geometry. In order to characterize this problem, an indicator describing the studied phenomenon was calculated. The necessity of this research results from the fact that the economic results of a farm are significantly influenced by the width, length, elongation and shape of plots. These parameters affect both the efficiency of field work and the amount of crop. According to Noga, the length of plots, taking into account using tractors, should be between 250 and $600 \mathrm{~m}$, while in case of a horse-drawn cart - $100 \mathrm{~m}$. The length of a plot depends on the way the land is used (on grassland from $290 \mathrm{~m}$, and on arable land up to $360 \mathrm{~m}$ ), as well as the density of roads [Noga 2005]. An important element when designing a parcel's area is its shape. Using the formula below, the elongation index was calculated for the villages of the Żarnów commune, from which we can deduce what the discrepancy between individual precincts is. To calculate the plot elongation rate, we needed the plot area and its perimeter. Table 3 presents the problem of elongation of plots in the Żarnów commune.

where:

$$
W_{k}=40 \cdot \pi \cdot \frac{p}{o^{2}}
$$

$W_{k}$ - shape coefficient,

$P$ - plot area,

$O$ - plot circumference.

According to the research, in Dąbie (Fig. 3) over 55.0\% of the number of plots is below the elongation index of 1.00. The opposite is the village of Siedlów, in which no plot is below the index. The next range includes the value of the elongation index from 1.01 to 2.00, in which the largest percentage of the number of plots belongs to the Malków precinct, for which $49.0 \%$ of the number of plots is in the range of 1.01 to 2.00 of the value of the elongation index, while the smallest percentage is in the village 
of Siedlów (3.0\%). In the range in which the value of the elongation index is from 2.01-3.00, the largest share belongs to the village of Zdyszewice, of which almost $25.0 \%$ of the number of plots is in the range of elongation index values 2.01-3.00, while the smallest share has the village of Staszowa Wola (9.0\%). In the studied area, the highest value of the elongation index is in Siedlów - 5.04, while the lowest is in Dąbie - 1.53.

Table 3. Plot geometry in the Żarnów commune

\begin{tabular}{|c|c|c|c|c|c|c|c|c|c|}
\hline \multirow[b]{2}{*}{$\begin{array}{l}\bar{\Xi} \\
: \bar{\Xi} \\
\overline{0}\end{array}$} & & \multicolumn{8}{|c|}{ Plot geometry } \\
\hline & 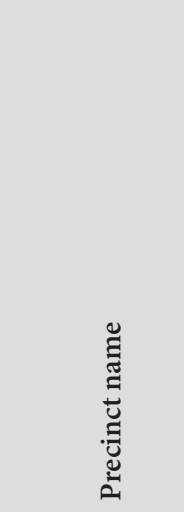 & 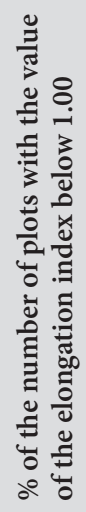 & 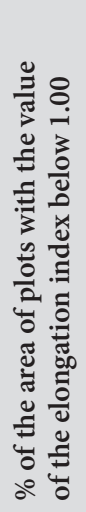 & 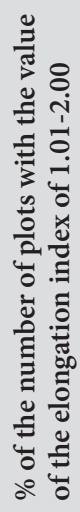 & 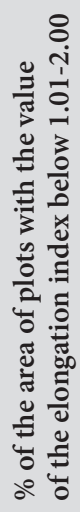 & 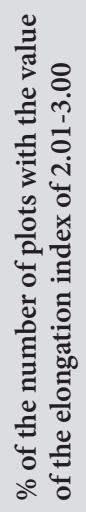 & 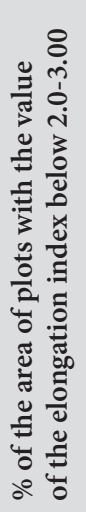 & 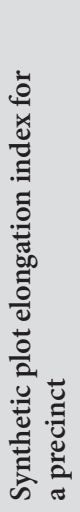 & 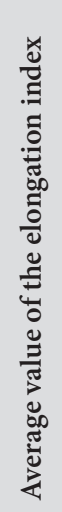 \\
\hline 1 & Adamów & 44.42 & 39.60 & 16.99 & 32.82 & 9.71 & 16.09 & 2.11 & 2.62 \\
\hline 2 & Afryka & 40.00 & 35.93 & 27.06 & 41.66 & 11.18 & 10.32 & 2.13 & 2.01 \\
\hline 3 & Antoniów & 30.10 & 38.16 & 26.09 & 34.87 & 19.73 & 15.56 & 2.08 & 2.12 \\
\hline 4 & Bronów & 1.45 & 0.48 & 5.09 & 3.13 & 18.91 & 18.77 & 4.69 & 4.32 \\
\hline 5 & Budków & 24.18 & 18.14 & 20.73 & 18.99 & 15.27 & 14.95 & 3.54 & 2.74 \\
\hline 6 & Chełsty & 19.18 & 15.15 & 15.72 & 20.54 & 11.95 & 12.21 & 3.71 & 3.51 \\
\hline 7 & Dąbie & 55.88 & 43.84 & 21.18 & 27.94 & 10.00 & 15.96 & 2.08 & 1.53 \\
\hline 8 & Dłużniewice & 1.56 & 1.02 & 11.46 & 4.78 & 19.79 & 15.83 & 4.46 & 3.88 \\
\hline 9 & Grębenice & 11.56 & 2.94 & 21.93 & 20.22 & 22.17 & 21.60 & 3.94 & 3.14 \\
\hline 10 & Jasion & 7.86 & 8.41 & 21.40 & 37.06 & 17.25 & 23.97 & 3.09 & 3.54 \\
\hline 11 & Klew & 10.75 & 10.83 & 24.73 & 44.91 & 16.13 & 21.67 & 2.72 & 3.13 \\
\hline 12 & Kolonia Klew & 18.23 & 10.13 & 28.96 & 26.49 & 19.08 & 22.37 & 3.32 & 2.75 \\
\hline 13 & Kamieniec & 11.70 & 5.25 & 29.24 & 23.92 & 21.64 & 17.99 & 3.70 & 2.86 \\
\hline 14 & Ławki & 23.53 & 11.44 & 23.90 & 11.36 & 13.60 & 15.88 & 4.13 & 2.90 \\
\hline
\end{tabular}




\begin{tabular}{|c|c|c|c|c|c|c|c|c|c|}
\hline 15 & Malenie & 14.61 & 14.26 & 41.57 & 46.78 & 17.42 & 22.04 & 2.56 & 2.58 \\
\hline 16 & Malków & 19.30 & 13.35 & 49.12 & 61.99 & 12.28 & 18.79 & 2.21 & 2.31 \\
\hline 17 & Marcinków & 13.73 & 7.30 & 20.17 & 19.58 & 22.03 & 26.06 & 3.68 & 3.20 \\
\hline 18 & $\begin{array}{l}\text { Miedzna } \\
\text { Murowana }\end{array}$ & 38.89 & 22.80 & 18.52 & 12.53 & 10.05 & 10.09 & 3.79 & 2.48 \\
\hline 19 & Młynek & 14.16 & 17.60 & 15.58 & 14.40 & 16.11 & 12.72 & 3.69 & 3.48 \\
\hline 20 & Myślibórz & 19.95 & 9.74 & 27.53 & 22.50 & 17.17 & 22.23 & 3.48 & 2.71 \\
\hline 21 & Nadole & 32.23 & 30.34 & 23.53 & 27.37 & 14.01 & 16.70 & 2.66 & 2.40 \\
\hline 22 & Niemojowice & 29.49 & 25.16 & 26.53 & 25.80 & 14.59 & 14.23 & 3.01 & 2.77 \\
\hline 23 & Nowa Góra & 11.56 & 4.18 & 14.61 & 17.03 & 22.74 & 23.55 & 3.91 & 3.36 \\
\hline 24 & Paszkowice & 15.45 & 14.55 & 26.02 & 31.67 & 16.26 & 17.29 & 3.08 & 2.94 \\
\hline 25 & Pilichowice & 17.50 & 19.66 & 23.38 & 22.01 & 17.63 & 16.64 & 3.32 & 3.01 \\
\hline 26 & Poręba & 34.32 & 22.46 & 24.89 & 25.19 & 12.74 & 17.40 & 3.10 & 2.31 \\
\hline 27 & Ruszenice & 8.00 & 3.11 & 20.67 & 14.62 & 22.67 & 26.47 & 4.02 & 3.33 \\
\hline 28 & $\begin{array}{l}\text { Kolonia } \\
\text { Ruszenice }\end{array}$ & 16.71 & 8.45 & 31.27 & 33.72 & 20.75 & 20.97 & 3.17 & 2.56 \\
\hline 29 & Siedlów & 0.00 & 0.00 & 3.08 & 3.85 & 12.31 & 8.28 & 4.95 & 5.04 \\
\hline 30 & Sielec & 1.15 & 0.06 & 4.30 & 2.78 & 20.63 & 20.63 & 4.60 & 4.36 \\
\hline 31 & Skórkowice & 0.60 & 1.12 & 8.72 & 5.97 & 22.71 & 18.20 & 4.55 & 4.14 \\
\hline 32 & Soczówki & 49.33 & 52.09 & 25.70 & 29.19 & 11.35 & 10.23 & 1.82 & 1.59 \\
\hline 33 & Straszowa Wola & 35.24 & 29.42 & 28.10 & 32.53 & 9.52 & 14.87 & 2.46 & 2.17 \\
\hline 34 & Tomaszów & 24.09 & 11.11 & 31.31 & 36.55 & 19.60 & 25.28 & 2.88 & 2.25 \\
\hline 35 & Topolice & 20.95 & 23.21 & 28.17 & 32.70 & 16.55 & 13.74 & 2.83 & 2.62 \\
\hline 36 & Trojanowice & 15.59 & 12.21 & 16.50 & 15.26 & 15.99 & 16.38 & 3.86 & 3.42 \\
\hline 37 & Widuch & 15.35 & 10.68 & 29.46 & 27.70 & 11.62 & 14.06 & 3.68 & 3.23 \\
\hline 38 & Żarnów & 8.63 & 3.65 & 11.51 & 6.84 & 21.58 & 18.39 & 4.26 & 3.58 \\
\hline 39 & Skumros & 22.80 & 14.87 & 26.77 & 24.90 & 13.58 & 12.82 & 3.59 & 2.73 \\
\hline 40 & Zdyszewice & 10.92 & 1.26 & 16.78 & 5.03 & 24.84 & 19.02 & 4.36 & 3.07 \\
\hline 41 & Wierzchowisko & 49.33 & 52.09 & 25.70 & 29.19 & 11.35 & 10.23 & 1.82 & 1.59 \\
\hline
\end{tabular}

Source: Authors' own study 


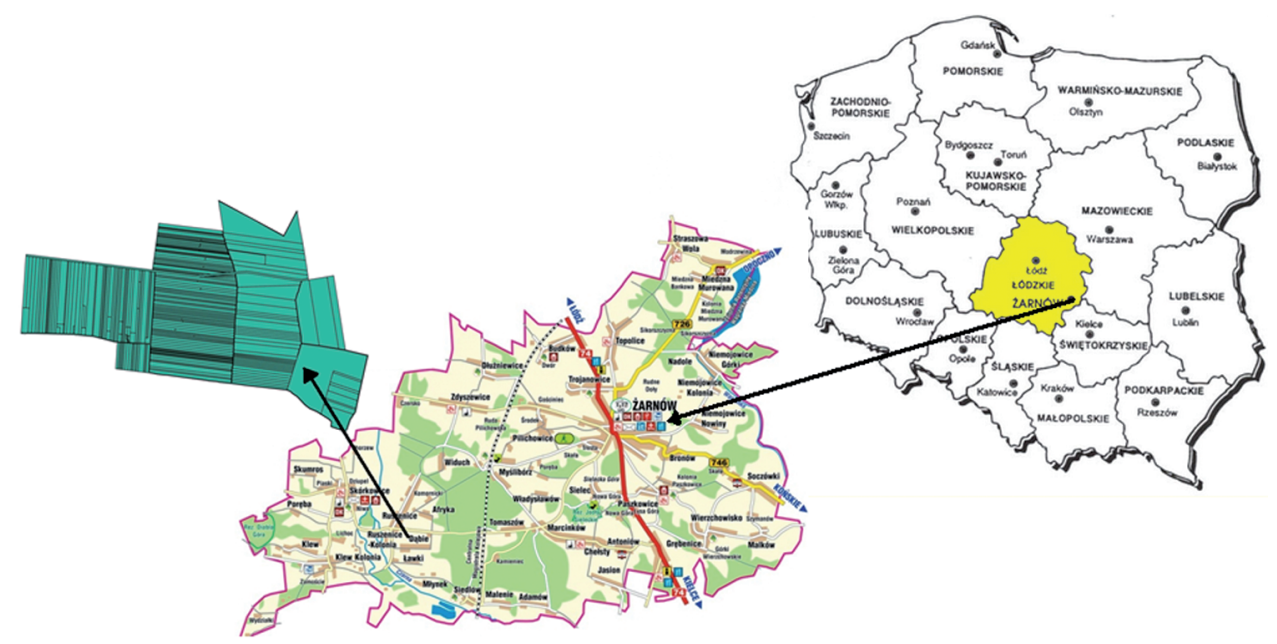

Source: Authors' own study

Fig. 3. Spatial structure of plots in the village of Dąbie

\section{Summary}

The current spatial structure of the villages is the result of long-term socio-economic and demographic processes leading to a continuous increase in the number of plots while reducing their area. Excessive fragmentation of farms occurring in the studied area affects the profitability of agriculture, in which nearly half of the commune's population finds employment. The analysis of the spatial structure of the Żarnów commune showed how important comprehensive land consolidation and exchange works are for this region. The wide spectrum of activities leading to the possibility of their implementation is aimed at rational use of land, improvement of agricultural production space, improvement of the access road system and thus the improvement of living and working conditions of the population. The research showed that it is possible to describe the objects to be consolidated by a number of factors characterizing them. Based on the conducted research, it was possible to obtain 32 factors that characterize the examined villages in detail. The first group includes factors describing general information about the studied precincts ( 7 factors). The second group consists of factors regarding individual farm lands ( 9 factors). The next group concerns the agricultural land and grassland productivity index ( 2 factors). The fourth group includes the factors regarding the structure of possession ( 2 factors). The fifth group includes factors informing about cadastral plots that do not have direct access to a public road (2 factors). The sixth group consists of factors regarding the structure of land use (2 factors). The last group provides information on the elongation of cadastral plots (8 factors).

Due to the complexity of work related to the creation of a new spatial order, it is important to determine the urgency and hierarchy of their implementation. The 
consolidation and exchange of lands at the same time throughout the entire examined area is impossible due to the large financial and human resources needed to implement this project. Therefore, they should be taken first where there is an urgent need. Appropriate selection of ranking methods will allow the calculation of a synthetic index, and thus determine the order in which land consolidation and exchange works will be carried out in the Żarnów commune.

\section{References}

Bentley J.W. 1987. Economic and ecological approaches to land fragmentation: in defense of a much-maligned phenomenon. Annual Review of Anthropology, 16, 31-67.

Blaiki P., Sadeque A. 2000. Policy in the high Himalayas: Environment and development in the Himalayan region. ICIMOD, Kathmandu.

Dijk Van T. 2003. Scenarios of Central European land fragmentation. Land Use Policy, 20, 149158.

Dijk Van T. 2004. Land consolidation as Central Europe's Panacea reassessed. Proceedings of Symposium on Modern Land Consolidation, September 10-11, Volvic (Clermont-Ferrand), France. http://www.fig.net/commission7/france_2004/papers_symp/ts_01_vandijk.pdf

Gulinck H., Wagendorp T. 2002. References for fragmentation analysis of the rural matrix in cultural landscapes. Landscape and Urban Planning, 58, 137-146.

Harasimowicz S., Janus J., Ostragowska B. 2012. Wpływ długości działek na ich dostępność z dróg i jego wykorzystanie do korekty dróg rolniczych. Infrastruktura i Ekologia Terenów Wiejskich, 1/II, Kraków.

Hartvigsen M. 2006. Land Consolidation in Central and Eastern European Countries. Shaping the Change. XXIII FIG Congress Munich, Germany, October 8-13.

Hudecová L., Geisse R., Vardžáková M., Turan P. 2016. Calculation of land fragmentation. Kartografické listy (Cartographic letters), 24(1), 12-22.

Hung P.V., Murata T. 2001. Impacts of reform policies on the agricultural sector in Vietnam. Journal of Faculty of Agriculture, Kyushu University, 46, 165-183.

Hung van P., MacAulay G.T., Marsh S.P. 2007. The economics of land fragmentation in the north of Vietnam. Australian Journal of Agricultural and Resource Economics, 51(2), 195-211.

Janus J., Mika M., Leń P., Siejka M., Taszakowski J. 2016. A new approach to calculate the land fragmentation indicators taking into account the adjacent plots. Survey Review, DOI: 10.1080/00396265.2016.1210362.

Karouzis G. 1977. Land ownership in Cyprus: Past and present. Strabo, Nicosia.

King R., Burton S. 1982. Land fragmentation: Notes on a fundamental rural spatial problem. Progress in Human Geography, 6(4), 475-494.

Kwinta A., Gniadek J. 2017. The description of parcel geometry and its application in terms of land consolidation planning. Computers and Electronics in Agriculture, 136, 117-124.

Latruffe L., Piet L. 2013. Does land fragmentation affect farm performance? A case study from Brittany, France. Working Paper Smart - Lereco N ${ }^{\circ} 13-04$.

Niroula G.S., Thapa G.B. 2005. Impacts and causes of land fragmentation, and lesson learned from land consolidation in South Asia. Land Use Policy, 22(4), 358-372.

Noga K. 2001. Metodyka programowania i realizacji prac scalenia i wymiany gruntów w ujęciu kompleksowym. Szkoła wiedzy o terenie. Kraków.

Noga K. 2005. Metodyka oceny struktury przestrzennej gruntów gospodarstw rolnych przed i po scaleniu. Zeszyty Towarzystwa Rozwoju Obszarów Wiejskich, Rzeszów, 30-37. 
Noga K., Leń P. 2010. Analiza rozdrobnienia gruntów indywidualnych we wsiach powiatu Brzozów. Infrastruktura i Ekologia Terenów Wiejskich, 3, 55-64.

Sonnenberg J. 2002. Fundamentals of Land Consolidation as an Instrument to Abolish Fragmentation of Agricultural Holdings. Paper, FIG XXII International Congress. Washington, D.C. $19-26.4 .2002,12$.

Radziszewska W., Jaroszewicz J. 2012. Ocena istniejącej sieci dróg transportu rolnego na obszarze wsi poddanej pracom scaleniowym. Acta Scientiarum Polonorum, ser. Geodesia et Descriptio Terrarum, 11, 3, 17-34.

Rahman S., Rahman M. 2008. Impact of land fragmentation and resource ownership on productivity and efficiency: The case of rice producers in Bangladesh. Land Use Policy, 26, 95-103.

Tan S., Heerink N., Qu F. 2006. Land fragmentation and its driving forces in China. Land Use Policy, 23(3), 272-285.

Vitikainen A. 2004. An Overview of Land Consolidation in Europe. Nordic Journal of Surveying and Real Estate Research, 1, 25-43.

Wenbo Li, Wang D., Li H., Liu S. 2017. Urbanization-induced site condition changes of periurban cultivated land in the black soil region of northeast China. Ecological Indicators, 80, September, 215-223.

Dr inż. Justyna Wójcik-Leń

Uniwersytet Przyrodniczy w Lublinie

Katedra Inżynierii Środowiska i Geodezji

e-mail: justyna.wojcik-len@up.lublin.pl

ORCID: https://orcid.org/0000-0002-1130-9156

Dr hab. inż. Izabela Skrzypczak, prof. PRz

Politechnika Rzeszowska

Katedra Geodezji i Geotechniki

ul. Poznańska 2, 35-959 Rzeszów

e-mail: izas@prz.edu.pl

ORCID: https://orcid.org/0000-0003-0978-3040

Dr inż. Grzegorz Oleniacz, prof. PRz

Politechnika Rzeszowska

Katedra Geodezji i Geotechniki im. Kaspra Weigla

ul. Poznańska 2, 35-959 Rzeszów

e-mail: oleniacz@prz.edu.pl

ORCID: https://orcid.org/0000-0003-3318-0928

Mgr inż. Karol Ożóg

Biuro Gospodarki Mieniem Miasta Rzeszowa

Plac Ofiar Getta, 35-002 Rzeszów

e-mail: karol.ozog@gamil.com

ORCID: https://orcid.org/0000-0002-2464-9010

Dr hab. inż. Przemysław Leń, prof. UP

Uniwersytet Przyrodniczy w Lublinie

Katedra Inżynierii Środowiska i Geodezji

ul. Akademicka 13, 20-950 Lublin

e-mail: przemyslaw.len@up.lublin.pl

ORCID: https://orcid.org/0000-0003-0810-9986 